\title{
Non-food applications of milk components and dairy co-products: A review
}

\author{
Jean-Luc AUDIC ${ }^{a *}$, Bernard CHAUFER ${ }^{\mathrm{a}}$, Georges DAUFIN ${ }^{\mathrm{b}}$ \\ a Laboratoire des Procédés de Séparation, Université de Rennes 1 (UC INRA), Campus de Beaulieu, \\ Bât. 10A, CS 74205, 35042 Rennes Cedex, France \\ ${ }^{\mathrm{b}}$ Laboratoire de Recherches de Technologie Laitière, INRA, 65 rue de Saint-Brieuc, \\ 35042 Rennes Cedex, France
}

(Received 31 March 2003; accepted 20 June 2003)

\begin{abstract}
Milk contains a lot of different components with their own functional properties and some of them, such as casein, have been used in the manufacture of non-food technical products for many years. The present review deals with the non-food applications of (i) the major individual components of milk: proteins (casein; soluble proteins); lactose; milk fat and (ii) whey, a co-product of cheese and casein manufacture. New applications of milk proteins on a laboratory scale are focused on the manufacture of protein-based films and biomaterials. Also, fermentation of lactose and whey provides low molecular weight compounds and exopolysaccharides. These promising routes for giving added value to dairy co-products and effluents should be applied to achieving a great reduction in dairy industry wastes.
\end{abstract}

\section{Non-food application / casein / lactose / whey / whey protein / milk fat / fermentation}

Résumé - Applications non-alimentaires des constituants du lait et des coproduits de l'industrie laitière : revue. Le lait est composé de différents constituants présentant chacun des propriétés fonctionnelles caractéristiques et ayant été valorisés dans le domaine non-alimentaire depuis de nombreuses années. L'objectif de cet article est de passer en revue ces applications nonalimentaires pour (i) les constituants individuels majoritaires du lait pris séparément à savoir : protéines (caséines ; protéines solubles), lactose, matière grasse ; et (ii) le lactosérum, co-produit de la transformation du lait en fromage ou en caséine. La fabrication de films et de biomatériaux à base de protéines apparaît comme l'une des applications les plus récentes et les plus attractives. D'autre part, la fermentation du lactose et/ou du lactosérum permet d'obtenir une grande variété de composés de faible masse molaire ainsi que des exopolysaccharides eux-mêmes valorisables. La variété des applications non-alimentaires répertoriées permet d'envisager différentes voies de valorisation pour les co-produits et les effluents de l'industrie laitière dans l'objectif de réduire au maximum les rejets.

Application non-alimentaire / caséine / lactose / lactosérum / protéine du lactosérum / matière grasse / fermentation

\footnotetext{
* Corresponding author: jean-luc.audic@univ-rennes1.fr
} 


\section{INTRODUCTION}

Milk and milk components are mostly used in foodstuffs in many different forms. Nevertheless, milk constituents also find numerous alternative applications in the non-food area such as in the manufacture of plastic materials [138], textile fibres [44], glues [143] or in the production of ethanol or methane [71]. Some of these technical applications have been well known for a long time, such as casein-based glues which were used in ancient Egypt [143], but novel uses are also proposed for opening new markets for components. Most of the technical applications are specific to one given milk component in relation to its structural and functional properties. Separation and extraction techniques may be of importance in the valorisation process of such individual components. Valuable components can be recovered by chemical and/or physical means in milk and dairy coproducts: casein is precipitated by adjusting $\mathrm{pH}$ to 4.6 [72], whey proteins are recovered by ultrafiltration [40], lactose is concentrated and crystallised from whey [64]. Besides, some applications concern the non-food uses of fractions containing different components together, which greatly simplify separation steps. This is the case for fermentation of dairy co-products such as whey converted to added value products [97].

The first part of the present review deals with the non-food uses of milk proteins, i.e. casein and whey protein, in relation to their structural and functional properties. Casein, the major protein in cow's milk, has a long history of use in the non-food area. This gaussian coil protein has been used since the beginning of the nineteenth century in the manufacture of a wide range of products including glues [143], rigid plastics [26, 101] and textile fibres [44], for example. Compared with casein, whey protein (about $6 \mathrm{~g} \cdot \mathrm{L}^{-1}$, obtained by filtration techniques) historically has found less numerous non-food applications. A few examples concern the cosmetic and phar- macological industries [58, 63] and the manufacture of protective films or coatings $[28,90]$.

In the second part of this review technical applications for lactose are discussed. Because of its low digestibility and solubility, lactose finds limited applications in the food area compared with some other sugars, making alternative applications of prime interest. In relation to its functional properties and the number of its reactive sites, lactose is used as a raw material for special applications, for example, in pharmacology [64], as substrate for fermentation of various products $[64,71,163]$ (methane, ethanol...) and in the synthesis of derivatives [145, 163] such as lactulose or lactitol, the best known examples. Particular attention was paid to non-food uses of lactose from whey. Whey, a co-product of cheese-making and casein industry, contains the water-soluble components of milk: lactose, whey proteins, salts and vitamins. Accordingly, fermentation processes focused on the bioconversion of the whole whey, as well as whole whey direct uses, are also described.

Finally, the last part of this review deals with the few non-food uses reported for milk fat, another major milk constituent.

\section{MILK PROTEINS}

\subsection{Casein and caseinates}

Casein is the main protein $\left(24-29 \mathrm{~g} \cdot \mathrm{L}^{-1}\right)$ in bovine milk, as shown in Table I. In fact, casein of milk, involved in highly hydrated micelles, is based on four major components, $\alpha_{\mathrm{s} 1}$-casein $(38 \%), \alpha_{\mathrm{s} 2}$-casein $(10 \%)$, $\beta$-casein $(36 \%)$ and $\kappa$-casein $(13 \%)$ and a minor constituent, $\gamma-\mathrm{CN}(3 \%)$. Each constituent varies in amino acid composition, molecular weight (19000-23 900), isoelectric point and hydrophilicity [72, 73].

Acid and rennet caseins are the two major types of casein available [72, 118], depending on the coagulation process. 
Table I. Protein distribution in cow's milk.

\begin{tabular}{|c|c|c|c|}
\hline Protein & & Content in $\mathrm{g} \cdot \mathrm{L}^{-1}$ & Relative proportion in $\%$ \\
\hline \multirow[t]{5}{*}{ Casein } & & 25 & 100 \\
\hline & $\alpha$-Casein & 12 & 48 \\
\hline & $\beta$-Casein & 9 & 36 \\
\hline & $\kappa$-Casein & 3.25 & 13 \\
\hline & Minor constituents & 0.75 & 3 \\
\hline \multirow[t]{6}{*}{ Whey proteins } & & 5.4 & 100 \\
\hline & $\beta$-lactoglobulin & 2.70 & 50 \\
\hline & $\alpha$-lactalbumin & 1.20 & 22 \\
\hline & Immunoglobulin & 0.25 & 5 \\
\hline & Serum-albumin & 0.65 & 12 \\
\hline & Proteoses-peptones & 0.60 & 10 \\
\hline
\end{tabular}

Acid casein refers to precipitated casein, obtained by adjusting skim milk $\mathrm{pH}$ to 4.6 with mineral acids such as hydrochloric or sulphuric acid. Lactic casein is precipitated by acidification due to lactic acid produced in situ with lactic acid bacteria designed as a starter. In rennet casein, coagulation is obtained by the action of chymosin (rennet), an enzyme which cleaves a chemical bond in $\kappa$-casein: the casein micelle is destabilised and forms a three-dimensional clot. Water-soluble caseinates can be obtained by solubilisation of caseins in alkali media such as sodium-, calcium-, potassium- or magnesium-hydroxyde, lime or borax [138]. The commercially available sodium caseinate is obtained by dissolution of acid casein in sodium hydroxide at a $\mathrm{pH}$ close to 7 .

Due to low frequency of secondary structures ( $\alpha$-helix and $\beta$-sheets) caseins are mostly random coil polypeptides with a high degree of molecular flexibility able to form typical intermolecular interactions (hydrogen, electrostatic and hydrophobic bonds) [31]. This confers upon caseins good film-forming and coating abilities [30, 41, 68]. The strongly amphipatic nature of caseins, arising from the balance of polar and non-polar amino acids resi- dues, causes them to concentrate at interfaces to form a protein film. This confers upon casein good emulsifying and stabilising properties.

Due to their high amount of polar groups, caseinate also shows good adhesion to different substrates such as wood, glass or paper and this hydrophilicity makes caseinate films excellent barriers to non-polar substances such as oxygen, carbon dioxide and aromas.

Chemical modification of casein can change protein-protein interactions and proteins' interactions with their environment in order to control specific properties. Crosslinking agents are difunctional compounds which react with free reactive groups to make covalent linkage between protein chains, leading to the formation of a three-dimensional network. Crosslinked materials generally exhibit improved physical and mechanical properties.

Considering these different properties, caseinate-based polymers can be used in several technical applications such as protective coating and foams, paper coating, adhesives or injection moulding disposables. The specific properties of casein relevant for technical applications are listed in Table II. 
Table II. Principal technical applications of casein and caseinates.

\begin{tabular}{|c|c|c|c|}
\hline Product & Property & Applications & Remarks/importance \\
\hline \multirow[t]{6}{*}{ Coating } & \multirow{6}{*}{$\begin{array}{l}\text { Film forming ability } \\
\text { Adhesion } \\
\text { Technical properties }\end{array}$} & Paint & Still used in some paints \\
\hline & & Ink & Still used \\
\hline & & Paper & Still used \\
\hline & & Packaging & To be developed \\
\hline & & Leather finishing & Historical \\
\hline & & Textile coating & Historical \\
\hline Adhesive & $\begin{array}{l}\text { Good processability } \\
\text { Bond strength } \\
\text { Water resistance obtained } \\
\text { by crosslinking }\end{array}$ & Water based glue & $\begin{array}{l}\text { Historical } \\
\text { Still used in some few } \\
\text { applications }\end{array}$ \\
\hline \multirow[t]{4}{*}{ Plastic } & \multirow{4}{*}{$\begin{array}{l}\text { Strength } \\
\text { Good mechanical properties } \\
\text { Water resistance obtained } \\
\text { by crosslinking }\end{array}$} & Rigid plastic & Historical \\
\hline & & Disposable & Historical \\
\hline & & Fibre & Historical \\
\hline & & $\begin{array}{l}\text { Coating } \\
\text { Film/foil in packa- } \\
\text { ging application }\end{array}$ & $\begin{array}{l}\text { To be developed } \\
\text { Laboratory scale }\end{array}$ \\
\hline Surfactant & $\begin{array}{l}\text { Surface tension } \\
\text { Stability of interface }\end{array}$ & Emulsifier, detergent & $\begin{array}{l}\text { Enhancement by chemical } \\
\text { modification }\end{array}$ \\
\hline
\end{tabular}

\subsubsection{Casein as an adhesive}

According to Tague [143], already in the days of the Egyptians and during the Middle Ages, cement and wood glues were made of casein. Casein glues were first manufactured in the early years of the nineteenth century and mostly used in woodworking [17]. At the beginning of the twentieth century, casein glues were formulated for the military aeroplane industry (plane structures were based on wood). A lot of formulations for casein-based glues have been published or patented until today $[17,120$, 126, 143]: in most cases, casein glues are available as a powder containing two main constituents, i.e. casein and an alkali, which are mixed in water before use (less than $24 \mathrm{~h}$ ). A third mixing chemical ingredient may also be added according to the formulas: lime or copper chloride to give water-resistant glues by promoting crosslinking of casein molecules, leading to insoluble material; dissociating agents such as ammonia or urea to limit the viscosity of the adhesive through lowered $\mathrm{H}$-bonds between caseinates; sodium silicate to extend working life, tannate or alkali tannate to increase adhesion.

Nowadays, casein glues, supplanted by synthetic glues in exterior woodworking, are still used in labelling adhesives, in the bottling industry, in interior woodworking [39] (plywood, door panels, Formica laminates...), in bonding paper or in pressure sensitive adhesives [124, 126].

\subsubsection{Casein as a coating or sizing agent}

In such utilisations, casein acts as a binder for the coating material, generally a mixture of mineral materials, which is applied as a thin layer on the surface of the material. 


\subsubsection{Paper industry}

The hydrophobic/hydrophilic balance of casein increases its affinity for pigments, its ink-binding properties and its adhesion to various substrates. In the paper industry, casein is used as size for high quality glazed papers or for fine halftone illustrations.

Water resistance can be achieved by exposure to formaldehyde vapours or by dipping in concentrated solutions of formaldehyde [116]. Formaldehyde or dialdehyde are crosslinking agents which bind free amino groups to protein to give a threedimensional network. For example, wallpaper becomes water washable by adding a coating of casein solution brushed over with a solution of formaldehyde.

With high solid contents (china clay, kaolin, chalk...) coating solutions become too viscous, so in some applications, flow modifiers are added to enhance the casting process. Viscosity can be lowered by reducing the molecular weight of caseins and by denaturing the protein. This can be achieved by addition of urea, by alkaline or enzymatic hydrolysis [100, 127], or by disulphide bond reducing agents such as mercaptoacetic acid or 2-mercaptoethanol $[119,148]$. Pigments can be directly mixed with the formula to obtain coloured size and coatings.

In the middle of the twentieth century, paper and board coating accounted for the major uses of casein [128]. Nowadays casein is still used in high quality paper finishing and for enamel grades of paper [107, 162], but a decline in the use of casein in paper coating can be mentioned due to casein's high costs (about $6 € / \mathrm{kg}$ in 2002).

\subsubsection{Textile industry}

Casein was first employed in an way analogous to that of the paper industry: textile fabrics are impregnated with a casein solution and cross-linked either by formaldehyde vapours or by dipping into a solution of crosslinker.
Such casein coatings promote resistance to abrasion, enhance pigment binding and allow the textile to be impervious to moisture when hardened [143].

Because of its film-forming and adhesive abilities, casein size also finds application in the textile industry [67].

Caseins combined with acrylates become a protective coating against greying of cotton [121]. Chemically-modified caseins, either grafted with acrylate esters or crosslinked, are used as anti-static finishing of natural (wool, cotton and silk) [49] and synthetic (polyester) [165] textile fibres.

\subsubsection{Leather industry}

Polyol plasticised casein [2] is used in the finishing operations in the leather industry combined with additional components such as acrylates [79], phenol derivatives, pigments for coloured products or binders such as gelatine or sulfonated castor oil [20]. The solution is coated on the leather before the surface is mechanically processed (brushed, ironed, glazed...) [137].

\subsubsection{Casein as a textile fibre}

In 1935, Ferretti patented a process for casein textile called "Lannital ${ }^{\circledR}$ " $[44,52$, 142]. An alkali-solution casein is spinned into a coagulation bath containing acid (sulphuric acid) and inorganic salts (aluminium and sodium salts). The spun fibres are insolubilised by dipping into a formaldehyde solution and water-washed [29, 74, 109].

Casein fibres are known under trade names such as Aralac ${ }^{\circledR}$ (USA), Casolana ${ }^{\circledR}$ (Netherlands) and Fibrolane ${ }^{\circledR}$ (UK) [157]. Casein fibres resemble wool and were mostly used during the Second World War, generally combined with other artificial or natural fibres such as wool, cotton, viscose and rayon. Casein polymer fibres have also been grafted with acrylonitrile to give bicomponent fibres $[14,140]$. Nowadays, commercial interest in casein fibres has declined, compared with more competitive synthetic fibres [137]. 


\subsubsection{Casein-based packaging films and biomaterials}

Transparency, biodegradability and good technical properties (barrier properties for apolar gases such as $\mathrm{O}_{2}$ and $\mathrm{CO}_{2}$ ) make casein films innovative materials for packaging. Nevertheless, casein-based materials have two major drawbacks in common with other protein-based biomaterials: limited mechanical properties and water sensitivity.

To overcome weakness and brittleness, plasticisers are added to enhance workability, elasticity and flexibility. Plasticisers reduce intermolecular hydrogen bonding while increasing intermolecular spacing. By decreasing intermolecular forces, plasticisers cause an increase in material flexibility but also a decrease in barrier properties due to increasing free volume. To summarise, an initially hard and brittle material becomes soft and flexible when plasticised enough.

For casein-based materials the most common plasticisers are polyols, sugars or starches owing to their miscibility with the protein and their ability to enhance elasticity and flexibility [6, 7, 69, 134-136].
Figure 1 shows a typical stress-strain curve obtained from a tensile test of a plasticised caseinate film and the derived mechanical properties (Tab. III): stress and elongation at break, elastic modulus (or Young's modulus) and stress at yield. The incorporation of polyol-type plasticizers (glycerol and sorbitol) in protein-based films causes a decrease in tensile strength and an increase in ultimate elongation. The major difference between protein- (casein or whey protein) based films and synthetic films (LDPE, HDPE and PVC wrap film) concerns elongation at break. The maximum elongation is rather low in plasticised protein-based samples (less than $85 \%$ ) compared with synthetic films (from $150 \%$ for plasticised PVC to $500 \%$ for LDPE), which may limit application domains for proteinbased films. Compared with starch-based materials, the most commonly used substitute for synthetic polymers, milk protein-based films exhibit better mechanical properties.

The second drawback of caseinate films deals with their water sensitivity and water vapour permeability. Mixing the protein with oils, waxes or acetylated monoglycerides $[23,24,78]$ is an easy route to drastically reduce water sensitivity. Casein can

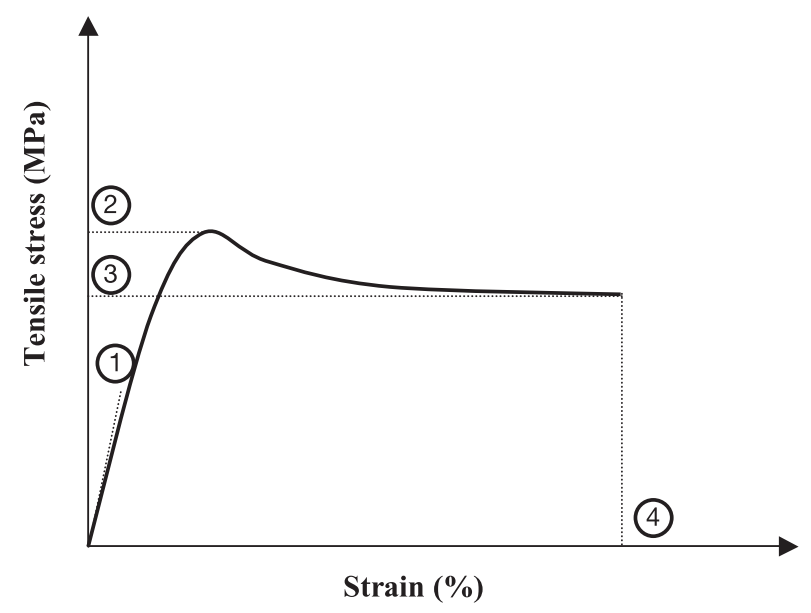

Figure 1. Typical stress-strain curve for caseinate-based films. (1) Young's modulus; (2) Tensile strength \& stress at yield; (3) Stress at break; (4) Elongation at break. 
also be hydrophobised by attachment of hydrophobic ligands, generally alkyl groups incorporated by esterification or by using monofunctional aldehydes [9, 22, 78, 87, 102]. Water sensitivity of caseinate films can also be reduced by crosslinking with (i) calcium ions [9, 115]; (ii) transglutaminase $[66,84,98]$; (iii) $\gamma$-irradiation [16, 96, 115]; and (iv) formaldehyde or dialdehydes $[62,80]$. On the other hand, the resulting three-dimensional casein network gives a rigid material with both a higher Young's modulus and tensile strength and with reduced elongation at break than plasticised casein.

As for other proteic materials, caseinbased films are hydrophilic, making them excellent gas barriers to non-polar substances such as oxygen, carbon dioxide and aromas. As a general trend, barrier properties of polymers depend on polymer structure and its segmental mobility, which influences its mass transport properties. Therefore, two main factors control its per- meability: the degree of binding between two polymer chains, and conversely, the free volume between two chains. Thus, the barrier properties of casein-based films are strongly modified by additives such as plasticisers or by chemical modification.

To overcome the problem of environmental pollution by synthetic polymers and with regard to their specific properties, protein-based biopolymers have gained growing interest in the last decade and represent an emerging field [39]. Caseinbased films and biomaterials obtained from caseinates can find many applications in packaging $[72,73,78]$, in edible films and coatings for fruits and vegetables $[12,22$, 78] or in mulching films [39]. Nevertheless, research on the technical alternative uses of protein has been limited so far compared with some other common biopolymers, especially starches. The higher cost of casein compared with common polysaccharides could be compensated for by the best properties and performances of

Table III. Comparison of tensile strength and elongation at break of natural and synthetic packaging films.

\begin{tabular}{lccc}
\hline \multicolumn{1}{c}{ Film } & $\begin{array}{c}\text { Tensile strength } \\
(\mathrm{MPa})\end{array}$ & $\begin{array}{c}\text { Elongation at break } \\
(\%)\end{array}$ & Ref. \\
\hline NaCAS/Glycerol (4:1) & $17.4-26.7$ & 10.5 & {$[134]$} \\
NaCAS/Glycerol (2:1) & $10.9-11.7$ & $73.7-84.2$ & {$[134]$} \\
NaCAS/PEG (4.54:1) & $10.9-16.35$ & 5.3 & {$[134]$} \\
NaCAS/PEG (1.9:1) & $10.9-13.9$ & 25.4 & {$[134]$} \\
WPI/Glycerol (5.7/1) & 29.1 & 4.1 & {$[90,91]$} \\
WPI/Glycerol (2.3/1) & 13.9 & 30.8 & {$[90,91]$} \\
WPI/Sorbitol (2.3/1) & 14.0 & 1.6 & {$[90,91]$} \\
WPI/sorbitol (1/1) & 14.7 & 8.7 & {$[90,91]$} \\
Starch/Glycerol (2.52/1) & 17.2 & 10.8 & {$[7]$} \\
LDPE & 13.0 & 500 & {$[91]$} \\
HDPE & 26.0 & 300 & {$[91]$} \\
Plasticized PVC & $15.0-30.0$ & $150-350$ & This work \\
(wrap film) & & & \\
\hline
\end{tabular}

NaCAS: sodium caseinate; PEG: polyethylene glycol; WPI: whey protein isolate; LDPE: low density polyethylene; HDPE: high density polyethylene.

${ }^{\mathrm{a}}$ Test conditions: $23{ }^{\circ} \mathrm{C}$ temperature, $50 \%$ relative humidity $(\mathrm{RH}) ;{ }^{\mathrm{b}}$ ratio in parentheses refers to the weight ratio of protein to plasticiser. 
protein-based biomaterials. For non-food applications, casein issued from waste streams should be a convenient way to save costs.

\subsubsection{Rigid casein plastics}

Rigid plastic based on rennet casein is one of the best-known examples of nonfood application for milk protein [138, 143]. Rennet casein and fillers are mixed with $20-35 \%$ water before being mechanically processed by high pressure extrusion into plastic goods, which are cured for a period of several days in a dilute solution of formaldehyde [26, 101, 111]. Any suitable pigment or colouring matter can be added. Casein plastic was first available in France and Germany under the trade name of "Galalith ${ }^{\circledR}$ " in the early twentieth century but other casein plastics have been patented under the trade names of Erinoid ${ }^{\circledR}$ (UK), Aladdinite ${ }^{\circledR}$ (USA), Casolith ${ }^{\circledR}$ (Netherlands), Lactoloid $^{\circledR}$ (Japan) and Lactolithe ${ }^{\circledR}$ (France). The importance of casein plastics has now declined due to severe competition from synthetic plastics with better properties. Although casein plastics are still manufactured today into buttons, buckles and imitation-ivory knife handle, the range of articles is becoming more and more limited compared with the increasing number of articles made of synthetic plastics.

\subsubsection{Casein as an additive}

Considering their amphipatic nature, caseins are often used as emulsifiers or stabilisers in numerous formulations where casein does not constitute the major constituant.

\subsubsection{Paints}

Because of its solubility and ability to bind pigments, caseinate has found applications in water-based paints [46, 130, 154]. Caseinate's emulsifying properties make it a good stabiliser and emulsifier in oil and latex paints. Its content in such formulas does not exceed 1 to $2 \%[53,123$, 124].

\subsubsection{Concrete and cement}

For its adhesive and emulsifying properties, caseinate is used (or claimed so) in concrete formulation in Eastern Europe, as well as cement, asphalt and bitumen [106, $110,138]$.

\subsubsection{Cosmetics}

Caseinate is used as surface active agent in soaps [1] and various cosmetics such as cold wave lotions, hair sprays and hand cream [125]. Casein hydrolysates could also be active substances for skin hydration [27]. However, little information is available about these applications and their markets, which seem rather limited.

\subsubsection{Other industrial applications}

Casein presents good metal- and ionbinding properties, making it suitable for absorbing and recovering chromate in wastes from manufacturing processes such as electroplating $[36,37]$ and water purification [155]. In rubber products, casein has been used as a reinforcing agent and stabiliser in rubber tyres [42, 54]. Casein and caseinate are also used in several other nonfood applications such as dish-washing liquids $[1,114,156]$.

\subsection{Whey proteins}

Whey proteins, 15 to $22 \%$ of the total milk proteins, are generally separated from whey by a membrane process as whey protein concentrates (WPC) or whey protein isolates (WPI) [40, 50, 164]. WPC have a protein content ranging from 30 to $90 \%$ [77] while WPI contains more than $90 \%$ protein in the dry matter. The two most abundant proteins in whey are $\beta$-lactoglobulin and $\alpha$-lactalbumin as shown in Table I. Most of the non-food uses of whey proteins deal with specific properties of single proteins used in cosmetology and pharmacology [75]. $\beta$-lactoglobulin and $\alpha$-lactalbumin are used as hydrating and antiwrinkle agents [27]. Lactoferrin can prevent formation of free radicals through its 
iron-chelating property [27]. In the 90s, whey proteins were also employed as an antianemic preparation in the form of iron proteinate [33].

There is an increasing economical and environmental need for finding new applications for whey proteins [117]. The physical and functional properties of whey proteins to be outlined are: solubility, viscosity, cohesion and adhesion, emulsifying properties, water sorption and gel-forming properties [76]. For example, the filmforming ability of whey proteins has been used for the production of protective films and coatings [28, 90-92]. The mechanical and physical properties of whey proteinbased material are improved by plasticisation [90-92] (Tab. III) and/or crosslinking [82]. Whey proteins are also used in paper coating to provide good appearance, printability and low water vapour permeability [59]. Because of their natural origin and emulsifying properties, whey proteins are used as substitutes for synthetic surfactants in the formulation of non-aggressive creams and shampoos. Whey protein hydrolysates have also been used in cosmetology (shampoos and hair creams) and pharmacology $[58,63,75]$.

\section{LACTOSE}

Lactose is the characteristic carbohydrate of bovine milk, present at approximately $4.8 \%$ (wt/vol) [161]. The major part of lactose produced each year is recovered from whey (Fig. 2). The pure lactose recovery process generally involves concentration by evaporation, crystallisation, separation, refining, drying and milling.

Because of its physical, chemical and functional properties, lactose, which is a disaccharide of glucose and galactose, is used to produce some derivatives. The milk sugar contains a number of reactive sites (glycosidic linkages, reducing group of glucose, free hydroxyl groups and carboncarbon bonds) that can be chemically or enzymatically modified.

The major uses of lactose include food ingredient, ingredient in infant formulae, filler or coating agent for tablets in the pharmaceutical industry, raw material for lactose derivatives and substrate for fermentation. However, lactose finds somewhat limited application in food products because of its low digestibility and poor solubility (ability to crystallise) [61, 64, 161]. Accordingly, the food industry only uses a small part of the lactose produced each year, making lactose non-food applications of prime interest. Considering the high biological oxygen demand of lactose [88] (BOD about 35-45 mg per litre of whey) the dairy industry needs to discover uses for lactose as well as for whey itself in order to dispose of these co-products in some environmentally acceptable way. Several valuable products from lactose have then been proposed in order to reduce the huge amounts of dairy effluents.

Most of the non-food uses deal with fermentation of whole whey (review in a following section; Fig. 2). Other non-food uses of lactose include raw material for lactose derivatives, pharmaceutical and cosmetic formulations [64]. For pharmaceuticals, raw lactose is mostly used as a filler, drug carrier and coating agent to cover tablets. Lactose has also been proposed as an inducer for overexpression of protein in genetically engineered organisms [103].

\subsection{Derivatives of lactose by chemical and enzymatic modification}

The use of lactose as a raw material in the chemical industry has been reviewed in detail by Zadow [163] and Thelwall [145]. Although the chemistry of lactose has made rapid progress over the past 30 years, the use of lactose as a chemical feedstock is only now being fully considered. 


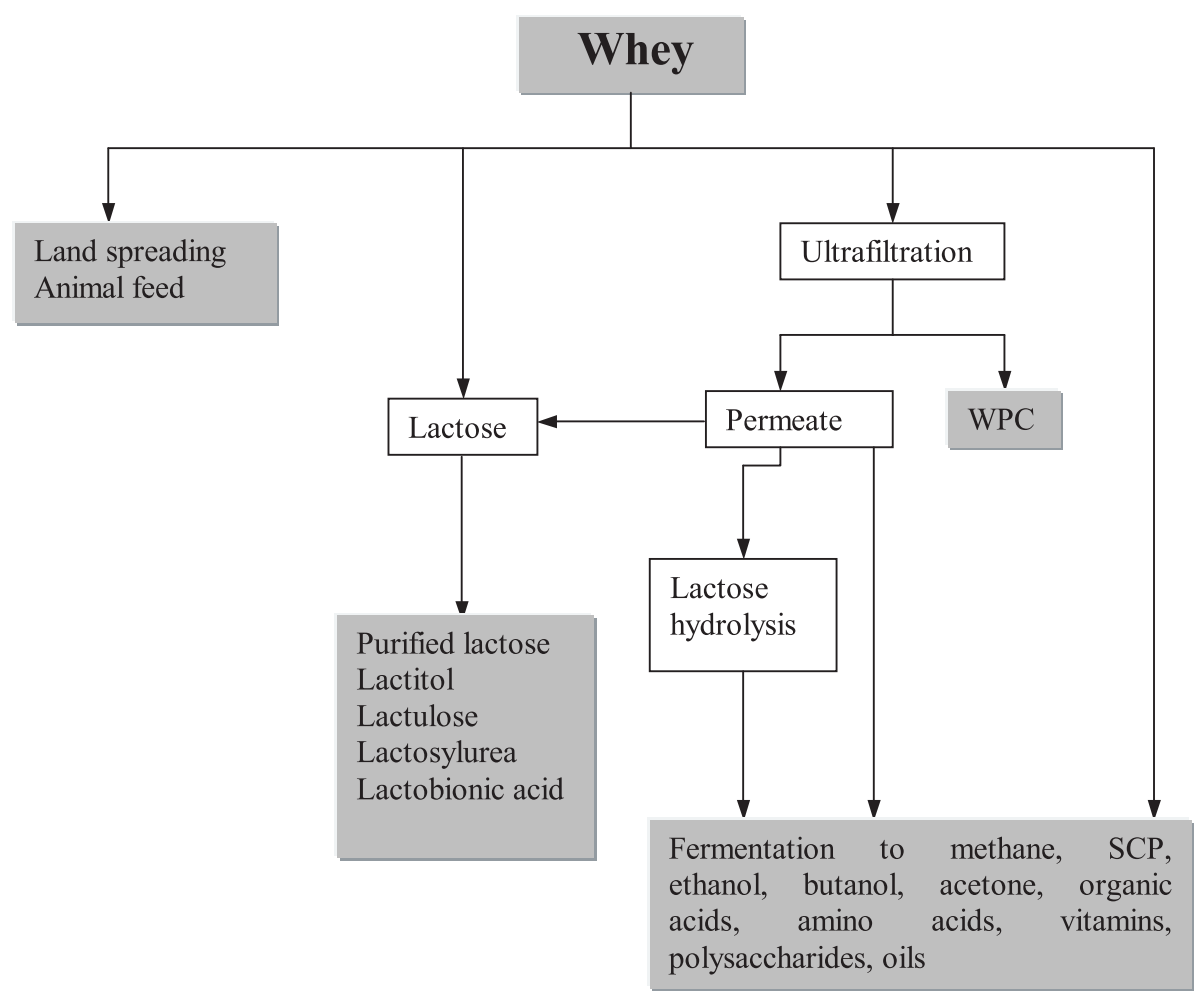

Figure 2. Utilisations of whey (SCP: Single cell protein and WPC: whey protein concentrate).

The lactose derivatives of great interest for applications in the non-food area are [64]:

- lactulose [93], an isomer of lactose produced by alkali hydroxide catalysis and widely used in pharmaceuticals (laxative) or as a growth promoter for pigs and calves [60, 161];

- lactitol [60, 122], issued from reduction of lactose, is used as a raw material for ester emulsifiers manufacture. These excellent surfactants are used in detergents, surface modifiers and emulsifiers. Lactitol also finds application in humectants, plasticisers, lacquer additives and hot melt additive adhesives [145];

- lactobionic acid [60], obtained by catalytic oxidation of the free aldehyde group of lactose. It finds applications as a gel-firming agent and in the composition of the preservation solution for organs prior to transplantation;

- lactosyl urea obtained by reaction of lactose with urea, described as a potential feedstock for ruminants because of increased palatability and reduced toxicity [163].

Other lactose derivatives of commercial interest such as galacto-oligosaccharides or hydrolysed lactose syrup are mostly used in the food industry [61, 161]. New lactose derivatives have also been described such as esters, halogenated derivatives, lactosyl halides, lactosides, anhydro derivatives, cyclic acetal derivatives, deoxy derivatives, nitrogen-containing derivatives and unsaturated derivatives. 
Some other attempts have been made to valorise lactose from whey permeate obtained by ultrafiltration (UF) techniques and corresponding to a deproteinated whey (Fig. 2). Such an UF whey permeate is used in the formulation of phenol-formaldehyde resins such as plywood adhesives [150152]: up to $50 \%$ weight substitution of phenol by a whey permeate-based modifier can be reached without significant loss of properties. Whey permeate is also used for the preparation of special polyurethane foams [153], lactose working as the chain extender in the place of polyols.

\subsection{Fermented products from lactose/whey}

Whey is the main source of lactose (Fig. 2) and most of the non-food applications proposed for lactose concern direct fermentation of whole whey [64, 71, 97, 163]. Whey is composed of mainly water (about 93\%), lactose (4.9 to 5.1\%), soluble proteins $(0.9$ to $1 \%)$, ash $(0.5$ to $0.7 \%)$, fat (0.1 to $0.3 \%)$ and lactic acid (0 to $0.2 \%)$ [76]. To make $1 \mathrm{~kg}$ of cheese, approximately $9 \mathrm{~kg}$ of whey is generated $[55,77]$ and world cheese production generates more than $145 \times 10^{6} \mathrm{t}$ of liquid whey per year, of which $6 \times 10^{6} \mathrm{t}$ is lactose. Fermentation can thus be a solution to give added value to cheese whey that could otherwise be disposed of as a waste stream generating high BOD. Fermentation thus also contributes to the reduction in dairy waste streams.

A wide range of products, summarised in Table IV, can be obtained from lactose or whey fermentation $[48,55,56,64,76$, 89]. According to Atkinson and Mavituna [8] they are classified into 3 categories:

(i) high volume - low value: methane, ethanol, biomass, animal feed, water purification, effluent and waste treatment;

(ii) high volume - intermediate value: amino acids, organic acids, food products, Baker's yeast and biopolymers;

(iii) low volume - high value: antibiotics, health care products, enzymes and vitamins.
However, lactose hydrolysis is often a step prior to fermentation (Fig. 2): microorganisms, unable to ferment lactose, are able to ferment hydrolysed lactose, allowing a wide variety of fermentation products. For most of the processes, lactose hydrolysis involves an increase in the process costs. Hydrolysis of the $\beta$-glycosidic bond into glucose and galactose can be performed with either enzymes such as $\beta$-D-galactosidase (lactase) or acid catalysis [55, 64, 76, 97]. Hydrolysis processes developed from pilot to industrial scale have been reviewed by Axelson and Zacchi [10] with respect to their economic feasibility. In whole whey fermentations, soluble proteins bring a part of the nitrogen source needed for the development of microorganisms. However, in most processes dealing with whole whey fermentation, it is necessary to have an extra nitrogen source or to hydrolyse whey protein to achieve good growth and productivity.

\subsubsection{Methane production by anaerobic digestion}

The production of methane or biogas via fermentation of whey is a process composed of three successive steps: lactose (and protein) hydrolysis, fermentation and methanogenesis [141]. This complex process involves several mixed bacterial species. According to Figure 3, the methanogenic process converts around $90 \%$ of hydrolysed organic matter to biogas: $\mathrm{CH}_{4}$ and $\mathrm{CO}_{2}$ [5]. Methane production via cheese whey anaerobic fermentation should thus represent an important source of energy as fuel or to generate electricity: theoretically, $1 \mathrm{~kg}$ of lactose yields $0.75 \mathrm{~m}^{3}$ of biogas containing approximately $50 \% \mathrm{vol} / \mathrm{vol}$ methane [64]. For a deproteinated milk whey the theoretical yield is approximately $20.7 \mathrm{~m}^{3}$ methane $/ \mathrm{m}^{3}$ (equivalent to $18.6 \mathrm{~L}$ of fuel oil) $[64,76]$. But it is compulsory to overcome some problems specific to anaerobic digestion to reach these theoretical yields: the process may be slow to initiate, a long residence time is required and waste 
Table IV. Whey/lactose fermentations.

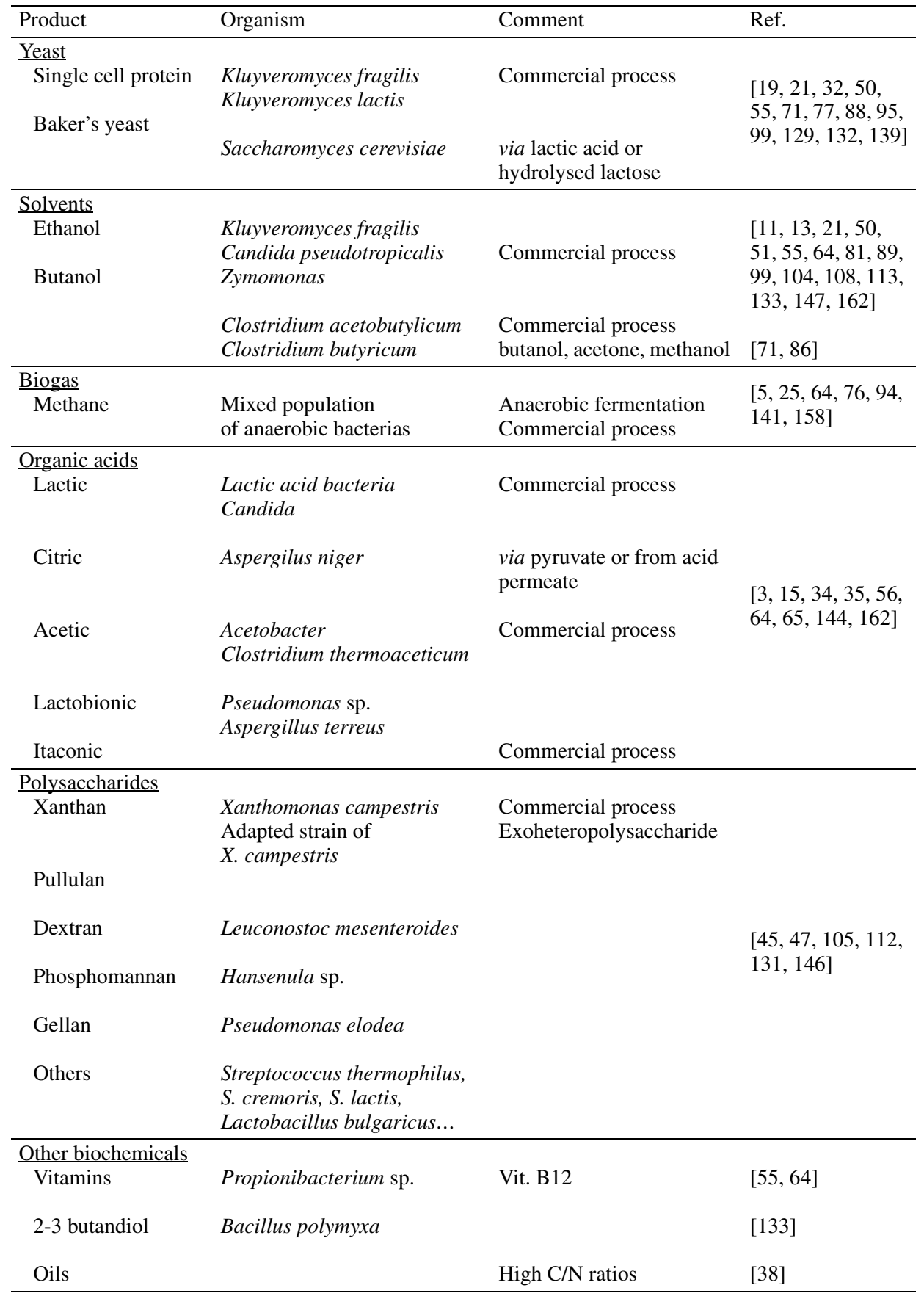




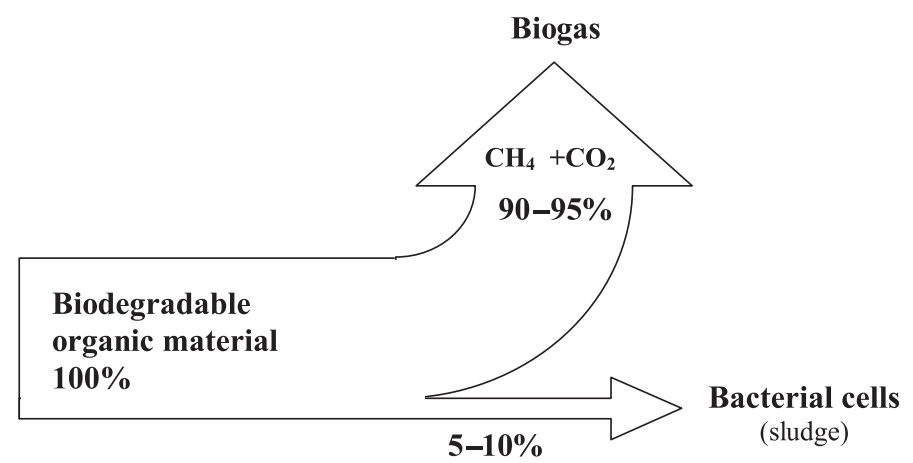

Figure 3. Anaerobic digestion of organic material, from [5]. streams of high BOD [141] are generated during fermentation. In consequence, the effluents generated by anaerobic processes are not suitable for pouring into water streams and post-treatments are required to reduce residual BOD. Several kinds of anaerobic digesters incorporating cell recycling or cell immobilisation have been studied $[5,25,94,141,158]$ and the development of the anaerobic process will depend on its economic feasibility.

\subsubsection{Single cell protein production (SCP)}

The use of lactose or whey as a carbon source for the production of yeast biomass is a simple treatment process for increasing the value of food industry co-products [32, $50,71,88,132]$. Several plants producing microbial biomass from cheese whey have been reported in France, the USA, Germany and Australia with two major processes known as the Bel Fromageries process and the Vienna process. If complete consumption of lactose is to be achieved it is necessary to add nitrogen and phosphorous [77]. Biomass produced from both batch and continuous processes $[19,21,88,95,99$, $129,139]$ is mostly used as animal feed supplement but also in production of baker's yeast. These processes are also of prime interest in dairy wastewater treatment: over $80 \%$ reduction in wastewater biological oxygen demand (BOD) has been observed [88] with a yield of dried yeast of $50 \%$ of the weight of the lactose used [55].

\subsubsection{Alcohol production}

Developments in whole whey utilisation also focused on the production of alcohols (mainly ethanol) [13, 51, 81, 89, 108]. High ethanol yields (about $80 \%$ ) can be reached from adapted Kluyveromyces fragilis strains. Ethanol can then be further used as an energy source (as fuel) or to produce vinegar or acetic acid. Several distilleries produce ethanol from whey in Ireland, the USA and New Zealand where about 50\% of cheese whey production is fermented to ethanol [55, 89]. Cheese whey generally contains carbon and nitrogen substrates (vitamins, fatty acids and sterols) required for microorganism growth. Lactose is first hydrolysed by $\beta$-galactosidase (from a micro-organism) and the resulting mixture of glucose and galactose is then used as the carbon source by Saccharomyces cerevisiae $[11,21]$.

Different processes based on continuous fermentation with cell immobilisation or cell recycling [64, 99, 104, 133, 147, 159] have been explored for production of ethanol. A recent alternative is to use recombinant yeast grown directly on cheese whey, allowing high yield of ethanol [113]. A mixture of acetone, butanol and ethanol (3/6/1:v/v) [71] can be obtained by fermentation of whey $[71,86]$, but the commercial 
potential of the technique seems low at the present time. 2-3 butanediol produced by fermentation of cheese whey has potential use in the chemical industry and as alternative energy source [133].

\subsubsection{Other fermented bioproducts}

\subsubsection{Organic acids}

Acetic, propionic, lactic, lactobionic, citric, gluconic and itaconic acids can be obtained from lactose/whey fermentation [3, 15, 34, 35, 56, 64, 65, 144, 159]. Most of them find applications in speciality chemicals. For example, lactic acid can be used to produce propylene oxide, biodegradable polylactic acid polymers, propylene glycol or acrylic fibres, making the lactic acid market of prime importance (about 27 million $\mathrm{kg}$ per year) [83, 85, 159]. Recent interest in biodegradable polymer could lead to enhanced demand for lactic acid. Acetic acid can also be selected as a raw material in the chemical industry for example to produce calcium magnesium acetate (CMA) used in large amounts as road or airport de-icer [159, 160]. Propionic acid is used in the production of feed and food additives, herbicides and chemical intermediates [64].

\subsubsection{Oils}

Production of lipids by special yeast under high $\mathrm{C} / \mathrm{N}$ ratios has been explored as an alternative source of oil for countries with poor domestic vegetable oils production (New Zealand) [38].

\subsubsection{Exopolysaccharides}

Extracellular microbial polysaccharides are mostly used as thickeners, emulsifiers and stabilisers in the food industry, but also in the textile industry $[64,76]$. Whey permeate is used as a substrate for the production of polysaccharides by fermentation [131], but lactose needs to be first hydrolysed before being fermented by commercial bacterial strains. For example, xanthan gum is an heteropolysaccharide produced by Xanthomonas campestris [105, 146]. Whey lactose has been widely used for the production of a large range of exopolysaccharides [45, 47, 64, 112]: dextrans (Leuconostoc mesenteroides), phosphomannans (Hansenula sp.), gellans (Pseudomonas elodea), pullulans (Aerobasidium pullulans), and several heteropolysaccharides (Streptococcus thermophilus, S. cremoris, S. lactis, Lactobacilus bulgaricus and L. pastorianus).

Adapted micro-organisms and processes can produce several different vitamins and amino acids from lactose whey fermentation [55, 64].

Among the most valuable products, exopolysaccharides ( $\$ 11$ to $17.6 / \mathrm{kg}$ ), calcium propionate $(\$ 4.4 / \mathrm{kg})$, lactic acid $(\$ 2.2 / \mathrm{kg})$ and potassium acetate $(\$ 1.06 / \mathrm{L})$ are obtained with good yields and present a potentially large market (Tab. V). Methane may also represent an interesting energy source for direct use on-site. It must be kept in mind that the prices of these products are useful only for comparison between each other and prices could vary in a relatively short time. For example, lactose price dropped from $\$ 0.6 / \mathrm{kg}$ to $\$ 0.3 / \mathrm{kg}$ during the last six months of 2002, depending on whey surplus. For lactic acid, the current worldwide production is estimated to be $40000 \mathrm{t}$ per year and the price is estimated at about $\$ 2 / \mathrm{kg}$. Currently, xanthan gum still costs about $\$ 11-12 / \mathrm{kg}$.

\section{MILK FAT}

Milk fat includes mono-, di- and triglycerides, fatty acids, cholesterol, milk fat globule membrane and phospholipids. According to Kaylegian [70] very few nonfood uses of milk fat have been proposed until now. Nevertheless, antimicrobial, antioxidant and anticarcinogenic properties have been attributed to lauric acid and conjugated linoleic acid, both fatty acids recovered from milk fat. With respect to its emollient 
Table V. Comparison of various products from $50000 \mathrm{~kg}$ of whey permeate (5\% lactose) ([159] with permission).

\begin{tabular}{lcccll}
\hline Product & Quantity & $\begin{array}{c}\text { Unit price } \\
\$\end{array}$ & $\begin{array}{c}\text { Value } \\
\$\end{array}$ & Use & $\begin{array}{l}\text { Market and } \\
\text { production }\end{array}$ \\
\hline Lactose & $1500 \mathrm{~kg}$ & $0.44 / \mathrm{kg}$ & 660 & Food, pharmaceutical & $95000 \mathrm{t} / \mathrm{yr}$ \\
Methane & $780 \mathrm{~m}^{3}$ & $0.176 / \mathrm{m}^{3}$ & 138 & Energy & On-site use \\
Ethanol & $1340 \mathrm{~L}$ & $0.40 / \mathrm{L}$ & 536 & Fuel & Large \\
CaMg-acetate & $3000 \mathrm{~kg}$ & $0.66 / \mathrm{kg}$ & 1980 & Road deicer & $<10000 \mathrm{t} / \mathrm{yr}$ \\
& & & & & potentially large \\
K-acetate & $6250 \mathrm{~L}$ & $1.06 / \mathrm{L}$ & 6625 & Airport runway deicer & $\sim 20 \times 10^{6} \mathrm{~L} / \mathrm{yr}$ \\
Lactic acid & $2250 \mathrm{~kg}$ & $2.2 / \mathrm{kg}$ & 4950 & Food, chemical and & $\sim 30 \times 10^{6} \mathrm{~kg} / \mathrm{yr}$ \\
& & & & polylactides & potentially large \\
Ca-propionate & $1500 \mathrm{~kg}$ & $4.4 / \mathrm{kg}$ & 6600 & Natural food preservative & $\begin{array}{l}\text { Small but good } \\
\text { Xanthan gum }\end{array}$ \\
$\begin{array}{l}\text { Transgalactosylated } \\
\text { oligosaccharides }\end{array}$ & $1750 \mathrm{~kg}$ & $11 / \mathrm{kg}$ & 19250 & Food thickener & $\sim 20 \times 10^{6} \mathrm{~kg} / \mathrm{yr}$ \\
\hline
\end{tabular}

properties, milk fat is claimed to be used in cosmetics in the manufacture of skin care creams and shampoo [4, 70]. Another example is the conversion of surplus milk fat into more profitable products: (i) fatty acids, diglycerides and monoglycerides obtained by lipase-catalysed glycerolysis of milk fat [18], and (ii) flavouring agents and detergents. The emulsifying properties of whey can be improved by addition of mono- and diglycerides issued from milk fat hydrolysis. However, in most of the nonfood applications, milk fat is used as a fatty acid reservoir to produce mono- and diglycerides that are mostly used in the manufacture of emulsifiers.

Milk fat has been proposed for the manufacture of edible and packaging films and protective coatings [43, 57]. Films made from milk fat or milk fat fractions exhibit low gas and water vapour permeability and improved hydrophobic properties [149].

\section{DAIRY EFFLUENTS}

Besides whey surplus, non-food uses can also be an alternative approach to give added value to industrial dairy effluents in compliance with environmental regulations. The process water of dairy effluents (excluding cleaning in place steps with chemical cleaning agents) is mainly composed of diluted milk and whey in a ratio depending on the type of product (cheese, powder, milk...) of the plant. At the present time part of these fluids are discarded in sewer systems $[89,161]$ or directly used without treatment (Fig. 2):

- as animal feed $[89,97,159]$. Whey represents a source of protein, lactose and minerals. For example, ruminants can take $30 \%$ of their dry matter requirements from liquid whey;

- as agricultural fertiliser [89, 97, 159, 161], with two important drawbacks: transport becomes very expensive due to the volume when whey is not concentrated enough and whey leaves saline deposits on soils.

Nevertheless, these ways of consumption of dairy effluents should be compromised by future requirements for safety and compliance with environmental regulations.

Within the frame of clean, sober and costeffective processes, the above-mentioned 
non-food applications should be applied to effluents. A first way is to concentrate effluents by appropriate techniques (membrane process, evaporation...) in order to obtain a solution able to be used in the target application. Fermentation appears to be the best way to give added value to such concentrated fluids through production of valuable compounds such as alcohol or exopolysaccharides. A second route, more restrictive, is to perform a selective recovery of an individual component (such as casein obtained by precipitation) in order to use it in the above-mentioned non-food applications. The cost of effluent treatment combined with the negligeable value of lost compounds is expected to be lower than the added value of non-food applications and the saving on treatment of sewer systems.

\section{CONCLUSION}

This review constitutes a survey of current and potential non-food applications of milk components, which provides new routes of commercial interest.

Milk non-food applications mostly deal with the major milk components: proteins, composed of casein and water-soluble proteins, lactose (purified or in whey) and fat. This review particularly focuses on some general applications in regard to the specific properties of each component.

Stickiness and viscosity as well as filmforming ability, explain why caseinate solutions are used in the manufacture of glues, coatings (paper coating and sizing agent), films and biomaterials. Casein is also an additive acting as an emulsifying agent in various products such as paints, concrete and cements or dish-washing liquids. Like caseins, soluble proteins are used in the manufacture of films and coatings and as an additive in several formulations, considering their emulsifying and gelforming properties. Single soluble proteins also find specific applications in cosmetology and pharmacology. Among the nonfood applications of milk proteins (casein and soluble protein), coatings, films and packaging are of great interest in the field of biodegradable and environmentallyfriendly polymers/materials.

Lactose is used as a raw material for the manufacture of derivatives such as lactitol, lactulose or lactobionic acid. Nevertheless, most of the non-food uses deal with the fermentation process of lactose providing a wide range of valuable products such as methane, alcohols, organic acids, baker's yeast, vitamins or exopolysaccharides. Fermentation of (hydrolysed) lactose from whey permeate or whole whey is an alternative way to contribute to the reduction in dairy waste streams.

Concerning milk fat, currently only a few non-food applications have been developed such as milk fat-based emollients or fatty acid production, but the commercial potential seems to be promising. Losses of milk fat are reduced compared with other components because it is the most valuable component in food applications. However, new markets need to be developed, as dairy and food products tend to reduce their fat content.

The non-food valorisations proposed in this paper for milk should also be applied to dairy wastes and co-products in order to reduce waste streams.

\section{REFERENCES}

[1] Abler R.L., Long life sudsing blend and pad, USA Patent 3788 999, 1974.

[2] Adamski J., Jabloska J., Leather coating agents, Poland Patent 135 323, 1986.

[3] Aeschlimann A., von Stockart U., The production of lactic acid from whey permeate by Lactobacillus helveticus, Biotechnol. Lett. 11 (1989) 195-200.

[4] Amerchol, Corp., Cremerol HMG product brochure, Pouring the natural goodness of milk into personal care. Amerchol, Edison, USA, 1994.

[5] Anonymous, Anaerobic treatment of dairy effluents, Bull. Int. Dairy Fed. 252 (1990) 3-23. 
[6] Arvanitoyannis I., Biliaderis C.G., Physical properties of polyol plasticized edible films made from sodium caseinate and soluble starch blends, Food Chem. 62 (1998) 333342.

[7] Arvanitoyannis I., Psomiadou E., Nakayama A., Edible films made from sodium caseinate, starches, sugars and glycerol, Carbohyd. Polym. 31 (1996) 179-192.

[8] Atkinson B., Mavituna F., Biochemical Engineering and Biotechnology Handbook, Macmillan, The Nature Press, New York, USA, 1983.

[9] Avena-Bustillos R.J., Krochta J.M., Water vapor permeability of caseinate-based films as affected by $\mathrm{pH}$, calcium crosslinking, and lipid content, J. Food Sci. 58 (1993) 904-907.

[10] Axelsson A., Zacchi G., Economic evaluation of the hydrolysis of lactose, Appl. Biochem. Biotechnol. 24/25 (1990) 679-684.

[11] Axelsson A., Nilsson M., Zacchi G., HahnHagerdal B., Performance of batch and continuous reactors with coimmobilized yeast and $\beta$-galactosidase, J. Chem. Technol. Biotechnol. 52 (1991) 227-241.

[12] Banerjee R., Chen H., Wu J., Mechanical strengths of milk protein based edible films affected by ultrasound treatment, J. Dairy Sci. 77 (suppl. 1) (1994) 24-30.

[13] Barry J.A., Alcohol production from cheese whey, Dairy Ind. Int. 47 (1982) 19-22.

[14] Blakey P.R., Perfitt W., Protein fibres, Rep. Progr. Appl. Chem. 51 (1966) 540-584.

[15] Blanc P., Goma G., Propionic acid and biomass production using continuous ultrafiltration fermentation of whey, Biotechnol. Lett. 11 (1989) 189-194.

[16] Brault D., D’Aprano G., Lacroix M., Formation of free standing sterilized edible films from irradiated caseinates, J. Agric. Food Chem. 45 (1997) 2964-2969.

[17] Browne F.L., Brouse D., Casein glues, in: Sutermeister E., Browne F.L. (Eds.), Casein and its Industrial Applications, 2nd edn., Reinhold Publishing Corporation, New York, USA, 1939, pp. 233-292.

[18] Callegarin F., Quesada-Gallo J.A., Debeaufort F., Voilley A., Lipids and biopackaging, J. Amer. Oil Chem. Soc. 74 (1997) 1183-1192.

[19] Castillo F.G., Lactose metabolism by yeast, in: Verachtert H., De Mot R. (Eds.), Yeast Biotechnology and Biocatalysis, Marcel Dekker, New York, USA, 1990, pp. 297-320.

[20] Cavett E.S., Casein in the leather industry, in: Sutermeister E., Browne F.L. (Eds.), Casein and its Industrial Applications, 2nd edn., Reinhold Publishing Corporation, New York, USA, 1939, pp. 354-365.

[21] Champagne C.P., Gioulet J., Lachance R.A., Production of baker's yeast in cheese whey ultrafiltrate, Appl. Environ. Microbiol. 56 (1990) 425-430.

[22] Chen H., Functional properties and applications of edible films made of milk proteins, J. Dairy Sci. 78 (1995) 2563-2583.

[23] Chen H., Wang W., Physical properties of milk protein emulsion films as affected by different melting points lipids, J. Dairy Sci. 77 (suppl. 1) (1994) 8.

[24] Chen H., Zhang S., Effects of protein-lipid and protein-plasticizer ratios on functional properties of sodium caseinate-acetylated monoglyceride films, J. Dairy Sci. 77 (suppl. 1) (1994) 8.

[25] Clark J.N., Utilization of acid and sweet wheys in a pilot-scale upflow anaerobic sludge blanket digester, J. Dairy Sci. Technol. 23 (1988) 305-327.

[26] Collins J.H., Casein Plastics and Allied Materials, The Plastic Institute, London, UK, 1952.

[27] Cotte J., Le lait, une matière d'avenir pour la cosmétique, Lait 71 (1991) 213-224.

[28] Coupland J.N., Shaw N.B., Monahan F.J., O'Riordan E.D., O'Sullivan M., Modeling the effect of glycerol on the moisture sorption behavior of whey protein edible films, J. Food Eng. 43 (2000) 25-30.

[29] Courtaulds L.T.D., Wormell R.L., Artificial threads, UK Patent 564 591, 1944.

[30] Courthaudon J.L., Girardet J.M., Compagne S., Rouhier L.M., Campagna S., Linden G., Lorient D., Surface active and emulsifying properties of casein micelles compared to those of sodium caseinate, Int. Dairy J. 9 (1999) 411-412.

[31] Creighton T.E., Proteins: Structure and Molecular Properties, Freeman, W.H., New York, USA, 1993.

[32] Cristiani-Urbina E., Netzahuatl-Munoz A.R., Manriquez-Rojas F.J., Juarez-Ramirez C., Ruiz-Ordaz N., Galindez-Mayer J., Batch and fed-batch cultures for the treatment of whey with mixed yeast cultures, Process Biochem. 35 (2000) 649-657.

[33] Dalev P.G., Utilization of waste whey as a protein source for production of iron proteinate: an antianemic preparation, Bioresource Technol. 48 (1994) 75-77.

[34] Daraktchiev R., Beschkov V., Kolev N., Aleksandrova T., Bioreactor with a semifixed packing: anaerobic lactose to lactic acid fermentation, Bioprocess Eng. 16 (1997) 115-117. 
[35] Datta R., Tsai S.P., Lactic acid production and potential uses: a technology and economics assessment, in: Saha B.C., Woodward J. (Eds.), Fuels and Chemicals from Biomass, ACS Symposium Series, Vol. 666, Washington, USA, 1997, pp. 224-236.

[36] Davey P.T., Williams D.R., Winter G., The use of crosslinked casein to recover chromate from solution, J. Appl. Biochem. 2 (1980) 60-65.

[37] Davey P.T., Houchin M.R., Winter G., Recovery of chromium from waste electroplating liquors by ion exchange on casein Part 1. Pilot plant studies, J. Chem. Technol. Biotechnol. A 33 (1983) 164-170.

[38] Davies J., Oil from whey, Food Technol. N. Z. 19 (1984) 33-37.

[39] De Graaf L.A., Kolster P., Industrial proteins as a green alternative for "petro" polymers: potentials and limitations, Macromol. Symposia 127 (1998) 51-58.

[40] Di Giacomo G., Del Re G., Spera D., Milk whey treatment with recovery of valuable products, Desalination 108 (1996) 273-276.

[41] Dickinson E., Ritzoulis C., Povey M.J.W., Stability of emulsions containing both sodium caseinate and tween 20 , J. Colloid Interface Sci. 212 (1999) 466-473.

[42] Dunlop Rubber Company Ltd., Fibres textiles enduites d'une composition adhésive, utilisables notamment pour le renforcement de caoutchoucs, et leur préparation, Fr. Patent 1371 652, 1964.

[43] Fairley P., German J.B., Krochta J.M., Phase behavior and mechanical properties of tripalmitin/butterfat mixtures, J. Food Sci. 59 (1994) 321-325, 327.

[44] Feretti A., Production of the artificial wool called Lannital from casein, Ind. Text. 54 (1937) 446-447.

[45] Fialho A.M., Martins L.O., Donval M.L., Leitao J.H., Ridout M.J., Jay A.J., Morris V.J., Sa-Correia I., Structures and properties of gellan polymers produced by Sphingomonas paucimobilis ATCC 31461 from lactose compared with those produced from glucose and from cheese whey, Appl. Environ. Microbiol. 65 (1999) 2485-2491.

[46] Flinn D.P., Improved paint compound, USA Patent 50 068, 1865.

[47] Frengova G.I., Simova E.D., Beshkova D.M., Simov Z.I., Exopolysaccharides produced by lactic acid bacteria of kefir grains, Z. Naturforsch. 57 (2002) 805-810.

[48] Friend B.A., Shahami K.M., Whey fermentation, N.Z. J. Dairy Sci. Technol. 14 (1979) 143-155.
[49] Frontczak-Wasiak I., Evaluation of the usefulness of modified casein as sizing agent for warp threads, Fibres Text. East. Eur. 7 (1999) 53-55.

[50] Gardner D., New technologies in the conversion of whey to high protein products, Mod. Dairy 68 (1989) 15-17.

[51] Gawel J., Kosikowski F.V., Improving alcohol fermentation in concentrated ultrafiltration permeates of cottage cheese whey, J. Food Sci. 43 (1978) 1717-1719.

[52] Genin G., The fabrication of artificial wool, Lait 17 (1937) 949-955.

[53] Genin G., Casein as a stabilizer for latex paint, Lait 38 (1958) 276-283.

[54] Genin G., The use of casein in the preparation of reinforcing agents for rubber, Lait 41 (1961) 44-50.

[55] Gonzalez Siso M.I., The biotechnological utilization of cheese whey: a review, Bioresource Technol. 57 (1996) 1-11.

[56] Goursaud J., Biotransformations du lactose, Ind. Alim. Agric. 103 (1986) 349-357.

[57] Greener Donhowe I., Fennema O., Edible films and coatings: characteristics, formation, definitions, and testing methods, in: Krochta J.M., Baldwin E.A., NisperosCarriedo M. (Eds.), Edible Coatings and Films to Improve Food Quality, Technomic Publ. Co. edn., Technomic Publ. Co., Lancaster, UK, 1994, pp. 1-24.

[58] Grollier J.F., L'OREAL S.A., Procédé de traitement des cheveux en vue d'améliorer leur aspect à l'aide d'une composition contenant un hydrolysat de lactalbumine, Fr. Patent 2471 778, 1981.

[59] Han J.H., Krochta J.M., Wetting properties and water vapor permeability of wheyprotein-coated paper, Trans. ASAE 42 (1999) 1375-1382.

[60] Harju M., Production and properties of lactulose, lactitol and lactobionic acid, Bull. Int. Dairy Fed. 289 (1993) 27-30.

[61] Harper W.J., Lactose and lactose derivatives, in: Zadow J.G. (Ed.), Whey and Lactose Processing, Elsevier Appl. Sci., London, England, 1992, pp. 317-360.

[62] Hayashida O., Mori F., Hasumi K., Endo A., Inhibition of glucan synthesis by casein polymer crosslinked by glutaraldehyde, Biosci. Biotechnol. Biochem. 62 (1998) 178-180.

[63] Hidalgo J., Jost R., Société des Produits Nestlé S.A., Cosmetic or therapeutic compositions for topical use, DE Patent 3001 300 A1, 1980.

[64] Hobman P.G., Review of processes and products for utilization of lactose in deproteinated milk serum, J. Dairy Sci. 67 (1984) 2630-2653. 
[65] Hwang S., Hansen C.L., Characterization of and bioproduction of short chain organic acids from mixed dairy-processing wastewater, Trans. ASAE 41 (1998) 795-802.

[66] Ikura K., Kometani T., Yoshikawa M., Sasaki R., Chiba H., Crosslinking of casein components by transglutaminase, Agric. Biol. Chem. 44 (1980) 1567-1573.

[67] Jackson D.L.C., Backwell A.R.A., Application of protein to wool to reduce felting. I. Casein, Aust. J. Appl. Sci. 6 (1955) 244-254.

[68] Jahaniaval F., Kakuda Y., Abraham V., Marcone M.F., Soluble casein fractions from $\mathrm{pH}$ and heat treated sodium caseinate: physicochemical and functional properties, Food Res. Int. 33 (2000) 637-647.

[69] Kalichevsky M.T., Blanshard J., Tokarczuk P., Effect of water and sugars on the glass transition of casein and sodium caseinates, Int. J. Food Sci. Technol. 28 (1993) 139-151.

[70] Kaylegian K.E., Functional characteristics and nontraditional applications of milk lipid components in food and nonfood systems, J. Dairy Sci. 78 (1995) 2524-2540.

[71] Kilara A., Patel M.T., Whey and lactose fermentation, in: Zadow J.G. (Ed.), Whey and Lactose Processing, Elsevier Appl. Sci., London, 1992, pp. 409-448.

[72] Kinsella J.E., Milk proteins: physicochemical and functional properties, CRC Crit Rev. Food Sci. Nutr. 21 (1984) 197-261.

[73] Kinsella J.E., Whitehead D.M., Brady J., Bringe N.A., Milk proteins: possible relationships of structure and function, in: Fox P.F. (Ed.), Developments in Dairy Chemistry-4-Functional Milk Proteins, Elsevier Appl. Sci., London, England, 1989, pp. 55-95.

[74] Koch P.A., Casein fibers: Fibrolane, Merinova, Caslen, Fibres Nat. Synth. 15 (1954) 242-244, 248.

[75] Kohler S., Zur Verwendung von Milch im Non-food-Bereich, Dmz. Lebensm. Ind. Milchwirtsch. 23 (1991) 696-702.

[76] Kosaric N., Asher Y.J., The utilisation of cheese whey and its components, Adv. Biochem. Eng. 35 (1985) 25-60.

[77] Kosikowski F.V., Whey utilization and whey products, J. Dairy Sci. 62 (1979) 1149-1160.

[78] Krochta J.M., Pavlath A.E., Goodman N., Edible films from casein-lipid emulsions for lightly-processed fruits and vegetables, in: Spiess W.E.L., Schubert H. (Eds.), Engineering and Food, Vol. 2, Preservation Processed Fruits and Vegetables, Elsevier Appl. Sci., New York, USA, 1990, pp. 329-340.
[79] Lakshminarayana Y., Vijayakumar M.T., Srinivasan K.S.V., Joseph K.T., Studies on the grafting of acrylonitrile-co-styrene onto casein, Eur. Polym. J. 22 (1986) 143.

[80] Latha M.S., Lal A.V., Kumary T.V., Sreekumar R., Jayakrishnan A., Progesterone release from glutaraldehyde crosslinked casein microspheres: in vitro studies and in vivo response in rabbits, Contraception 61 (2000) 329-334.

[81] Lazarova G., Ignatova M., The ethanol fermentation kinetics as a function of the substrate type and concentration, Biotekhnol. Biotekh. 3 (1991) 37-42.

[82] Le Tien C., Letendre M., Ispas-Szabo P., Mateescu M.A., Delmas-Patterson G., Yu H.L., Lacroix M., Development of biodegradable films from whey proteins by crosslinking and entrapment in cellulose, $\mathrm{J}$ Agric. Food Chem. 48 (2000) 5566-5575.

[83] Lipinsky E.S., Sinclair R.G., Is lactic acid a commodity chemical?, Chem. Eng. Progr. August (1986) 26-32.

[84] Lorenzen P.C., Schlimme E., Roos N., Crosslinking of sodium caseinates by a microbial transglutaminase, Nahrung 42 (1998) 151-154.

[85] Lunt J., Large-scale production, properties and commercial applications of polylactic acid polymers, Polym. Degrad. Stabil. 59 (1998) 145-152.

[86] Maddox I.S., Production of $n$-butanol from whey filtrate using Clostridium acetobutylicum, N.C.I.B.2951, Biotechnol. Lett. 2 (1980) 493-498.

[87] Mauer L.J., Smith D.E., Labuza T.P., Water vapor permeability, mechanical, and structural properties of edible beta-casein films, Int. Dairy J. 10 (2000) 353-358.

[88] Mawson A.J., Yeast biomass production from acid whey permeate, Biotechnol. Lett. 10 (1988) 503-508.

[89] Mawson A.J., Bioconversions for whey utilization and waste abatement, Bioresource Technol. 47 (1994) 195-203.

[90] McHugh T.H., Krochta J.M., Sorbitol- vs. glycerol-plasticized whey protein edible films: integrated oxygen permeability and tensile property evaluation, J. Agric. Food Chem. 42 (1994) 841-845.

[91] McHugh T.H., Krochta J.M., Milk-proteinbased edible films and coatings, Food Technol. 48 (1994) 97-103.

[92] McHugh T.H., Aujard J.F., Krochta J.M., Plasticized whey protein edible films: water vapor permeability properties, J. Food Sci. 59 (1994) 416-423. 
[93] Mendez A., Olano A., Lactulose: a review of some chemical properties and applications in infant nutrition and medicine, Dairy Sci. Abstr. 41 (1979) 531-535.

[94] Mendez R., Blazquez R., Lorenzo F., Lema J.M., Anaerobic treatment of cheese whey: start up and operation, Water Sci. Technol. 21 (1989) 1857-1860.

[95] Meyrath J., Bayer K., Biomass from whey, Econ. Microbiol. 4 (1979) 207.

[96] Mezgheni E., Vachon C., Lacroix M., Biodegradability behavior of crosslinked calcium caseinate films, Biotechnol. Progr. 14 (1998) 534-536.

[97] Morr C.V., Whey utilization, in: Zadow J.G. (Ed.), Whey and Lactose Processing, Elsevier Appl. Sci., London, England, 1992, pp. 133-155.

[98] Motoki M., Aso H., Seguro K., Nio N., $\alpha$-s1-casein film prepared using transglutaminase, Agric. Biol. Chem. 51 (1987) 993-996.

[99] Moulin G., Galzy P., Whey, a potential substrate for biotechnology, Biotechnol. Genet. Eng. Rev. 1 (1984) 347-374.

[100] Muller L.L., Hayes J.F., The manufacture of low-viscosity casein, Aust. J. Dairy Technol. 18 (1963) 184-188.

[101] Munro P.A., Southward C.R., Elston P.D., The effect of casein manufacturing variables on the properties of rennet casein plastics, N.Z. J. Dairy Sci. Technol. 15 (1980) 177-190.

[102] Nakai S., Li-Chan E., Chemical and enzymatic modification of milk proteins, in: Fox P.F. (Ed.), Developments in dairy chemistry-4-Functional milk proteins, Elsevier Appl. Sci., London, England, 1989, pp. 347-375.

[103] Neubauer P., Hofmann K., Holst O., Battiasson B., Kruschke P., Maximizing the expression of a recombinant gene in Escherichia coli by manipulation of induction time using lactose as inducer, Appl. Microbiol. Biotechnol. 36 (1992) 739-745.

[104] Nolan A.M., Barron N., Brady T., McAree T., Smith D., McHale L., McHale A.P., Ethanol production at $45^{\circ} \mathrm{C}$ by an alginate immobilized thermotolerant strain of Kluyveromyces marxianus following growth on glucose-containing media, Biotechnol. Lett. 16 (1994) 849-852.

[105] Papoutsopoulou S.V., Ekateriniadou L.V., Kyriakidis D.A., Genetic construction of Xanthomonas campestris and xanthan gum production from whey, Biotechnol. Lett. 16 (1994) 1235-1240.

[106] Parker J., Manufacture of bituminous emulsions, GB Patent 333 303, 1930.
[107] Patel M., Tripathy D.K., Calendering of talc based coated paper in the mill, Quart. J. Indian Pulp Pap.Tech. Assoc. 10 (1998) 101-113.

[108] Peeva L., Peev G., A new method for $\mathrm{pH}$ stabilization of the lactoacidic fermentation, Enzyme Microb. Technol. 21 (1997) 176-181.

[109] Peterson R.F., McDowell R.L., Hoover S.R., Continuous-filament casein yarn, Text. Res. J. 18 (1948) 744-748.

[110] Pilz E., Regenhardt O., Verfahren zur Darstellung echter Disazofarbstoffe für Druck und Färberei, German Democratic Republic Patent Application 62 133, 1967.

[111] Pinner S.H., Protein plastics and fibers. A review, Brit. Plastics 18 (1946) 313-318, 353-361.

[112] Pintado M.E., da Silva J.A.L., Pintado A.I.E., Malcata F.X., Rheological characterisation under shear of a fraction of polymer produced via fermentation of whey-related media by Rahnella aqualitis, Carbohyd. Polym. 37 (1998) 1-6.

[113] Porro D., Martegani E., Ranza B.M. Alberghina L., Development of high cell density cultures of engineered Saccharomyces cerevisiae cells able to grow on lactose, Biotechnol. Lett. 14 (1992) 1085-1088.

[114] Pötschke D., Verwendung von Casein als Reinigungsmittel, Eur. Patent 0244647 A2, 1987.

[115] Ressouany M., Vachon C., Lacroix M., Irradiation dose and calcium effect on the mechanical properties of cross-linked caseinate films, J. Agric. Food Chem. 46 (1998) 1619-1623.

[116] Ritson D.D., Greif D.S., Stonebraker M.E., Paper coating additives, in: Hall H.R. (Ed.), Tappi Monograph Series No. 22, Vol. 46, Technical Association of the Pulp and Paper Industry, New York, USA, 1963, pp. 600-605.

[117] Robinson B.P., Short J.L., Marshall K.A., Traditional lactalbumin - manufacture, properties and uses, N.Z. J. Dairy Sci. Technol. 11 (1976) 114-126.

[118] Roeper J., High-calcium phosphate casein products for use in food systems, N.Z. J. Dairy Sci. Technol. 11 (1976) 62-64.

[119] Ronai K.S., Weisberg S.M., Modified proteins for stabilizing latex paints, Ind. Eng. Chem. 46 (1954) 774-777.

[120] Ross J.H., Ross C.D., Improvement in processes of preparing glue, USA Patent 183 024, 1873.

[121] Rybicki E., Steele B., Hankiewicz J., Modified casein as a protective colloid in the 
washing bath, Fibres Text. East. Eur. 7 (1999) 56-60.

[122] Saijonmaa T., Heikonen M., Kreula M., Links P., Preparation and characterisation of milk sugar alcohol, lactitol, Milchwissenschaft 33 (1978) 733-736.

[123] Salzberg H.K., Casein stabilizers for latex paints, Paint Varn. Product. 44 (1954) 35-37, 77.

[124] Salzberg H.K., Casein, Encycl. Polym. Sci. Technol. 2 (1964) 859-871.

[125] Salzberg H.K., Processed milk casein for hair and skin cosmetics, Amer. Perf. Cosm. 82 (1967) 41-50.

[126] Salzberg H.K., Casein glues and adhesives, in: Skiest I. (Ed.), Hanbook of Adhesives, 2nd edn., van Nostrand Reinhold Company, New York, USA, 1977, pp. 158-171.

[127] Salzberg H.K., Simonds M.R., Borden Cie, Low viscosity casein, USA Patent 3186 918, 1965.

[128] Salzberg H.K., Marino W.L., Protein binders in paper and paperboard coating, in: Strauss R. (Ed.), Tappi Monograph Series No. 36, Technical Association of the Pulp and Paper Industry, Atlanta, USA, 1975, pp. 1-74.

[129] Sandhu D.K., Waraich M.K., Conversion of cheese whey to single-cell protein, Biotechnol. Bioeng. 25 (1983) 797-803.

[130] Scholz H.A., History of water-thinned paints, Ind. Eng. Chem. 45 (1953) 710-711.

[131] Schwartz R.D., Biopolymers from whey, Bull. Int. Dairy Fed. 212 (1993) 56-61.

[132] Shay L.K., Wegner G.H., Non-polluting conversion of whey permeates to food yeast protein, J. Dairy Sci. 69 (1986) 676-683.

[133] Sienkiewicz T., Riedel C.L., Whey and Whey Utilization: Possibilities for Utilization in Agriculture and Foodstuffs Production, Verlag Th. Mann, GelsenkirchenBuer, Germany, 1990.

[134] Siew D.C.W., Heilmann C., Easteal A.J., Cooney R.P., Solution and film properties of sodium caseinate/glycerol and sodium caseinate/polyethylene glycol edible coating systems, J. Agric. Food Chem. 47 (1999) 3432-3440.

[135] Somanathan N., Naresh M.D., Sanjeevi R., Mechanical properties of alkali treated casein films, Polym. J. 24 (1992) 603-611.

[136] Somanathan N., Naresh M.D., Arumugam V., Sanjeevi R., Mechanism of failure of hydrolyzed casein films, Eur. Polym. J. 36 (2000) 2485-2490.

[137] Southward C.R., Uses of casein and caseinates, in: Fox P.F. (Ed.), Developments in
Dairy Chemistry-4-Functional Milk Proteins, Elsevier Appl. Sci., London, England, 1989, pp. 173-243.

[138] Southward C.R., Walker N.J., The manufacture and industrial use of casein, N.Z. J. Dairy Sci. Technol. 15 (1980) 201-217.

[139] Stineman T.L., Edwards J.D., Grosskopf J.C., The Kroger Co., Production of baker's yeast from acid whey, USA Patent 4192 $918,1980$.

[140] Stratmann M., Synthetic bicomponent fibres, Chemiefasern Text.-Anwendungstech./ Text. -Ind. 23 (1973) 1117-1121.

[141] Stronach S.M., Rudd T.M., Lester J.N., Anaerobic Digestion Process in Industrial Wastewater Treatment, Springer-Verlag, Berlin, Germany, 1986.

[142] Sutermeister E., Browne F.L., Casein and its Industrial Applications, Reinhold Publishing Corporation, New York, USA, 1939.

[143] Tague E.L., Casein. Its Preparation, Chemistry and Technical Utilizations, Van Nostrand Company, New York, USA, 1926.

[144] Tango M.S.A., Ghaly A.E., Amelioration of lactic acid production from cheese whey using micro-aeration, Biomass Bioenerg. 17 (1999) 221-238.

[145] Thelwall L.A.W., Developments in the chemistry and the chemical modification of lactose, in: Fox P.F. (Ed.), Developments in Dairy Chemistry-3 Lactose and Minor Constituents, Elsevier Appl. Sci., London, England, 1985, pp. 35-67.

[146] Thorne L., Tansey L., Pollock T.J., Direct utilization of lactose in clarified cheese whey for xanthan gum synthesis by Xanthomonas campestris, J. Ind. Microbiol. 3 (1988) 321-328.

[147] Tin C.S.F., Mawson A.J., Ethanol production from whey in a membrane recycle bioreactor, Process Biochem. 28 (1993) 217-221.

[148] Towler C., Creamer L.K., Southward C.R., Reduction of casein viscosity, in: XX International Dairy Congress, Brief Communications, Congrilait, 26-30 June, Paris, France, 1978, pp. 909-910.

[149] Villeneuve P., Muderhwa J.M., Graille J., Haas M.J., Customizing lipases for biocatalysis: a survey of chemical, physical and molecular biological approaches, J. Mol. Catal. B Enzym. 9 (2000) 113-148.

[150] Viswanathan T., Identification of thermosetting adhesive resins from whey permeate as high molecular weight Maillard polymers, Ind. Eng. Chem. Prod. Res. Dev. 24 (1985) 176-177.

[151] Viswanathan T., Richardson T., Thermosetting adhesive resins from whey and 
whey by-products, Ind. Eng. Chem. Prod. Res. Dev. 23 (1984) 644-647.

[152] Viswanathan T., Toland A., Whey modified phenol-formaldehyde resins as plywood adhesives, Carbohyd. Polym. 15 (1991) 41-49.

[153] Viswanathan T., Burrington D., Richardson T., Preparation of rigid, low density, flame retardant polyurethane foams from whey permeate, J. Chem. Technol. Biotechnol. B 34 (1984) 52-56.

[154] Warth A.H., Browne F.L., Casein paints, in: Sutermeister E., Browne F.L. (Eds.), Casein and its Industrial Applications, 2nd edn., Reinhold Publishing Corporation, New York, USA, 1939, pp. 315-353.

[155] Wayman M., Salamat H., Dewar E.J., Chlorine exchange resins, Can. J. Chem. Eng. 46 (1968) 282-287.

[156] Winterbotham P., Hampson J.D., Lever Brothers LTD, Liquid detergent compositions having improved drain-dry and mildness properties, USA Patent 4144201, 1979.

[157] Wormell R.L., New fibres from protein, Butter Worths Publications Ltd, London, England, 1954.

[158] Yan J.Q., Lo K.V., Liao P.H., Anaerobic digestion of cheese whey using up-flow anaerobic sludge blanket reactor, Biol. Wastes 27 (1989) 289-305.

[159] Yang N., Silva E.M., Novel products and new technologies for use of a familiar carbohydrate, milk lactose, J. Dairy Sci. 78 (1995) 2541-2562.

[160] Yang S.T., Zhu H., Lewis V.P., Tang I.C., Calcium magnesium acetate (CMA) production from whey permeate: process and economic analysis, Resour. Conserv. Recycl. 7 (1992) 181-200.

[161] Yang S.T., Zhu H., Silva E.M., Production of value-added products from agricultural and food processing byproducts, in: Ayyanna C. (Ed.), Biotechnology in 21st century, Tate McGraw-Hill Publ. Co. Ltd., New Delhi, India, 1993, pp. 47-68.

[162] Yang S.T., Gao F., Yin Z., Chemical modified gelatin and its application in cast coated paper, China Pulp. Paper 19 (2000) 26-31.

[163] Zadow J.G., Lactose: properties and uses, J. Dairy Sci. 67 (1984) 2654-2679.

[164] Zall R.R., Trends in whey fractionation and utilization: a global perspective, J. Dairy Sci. 67 (1984) 2621-2629.

[165] Zawadzki A., Antistatic finishing of synthetic fiber textiles, PL Patent 176 001B, 1999.

To access this journal online: www.edpsciences.org 